\title{
Perencanaan Bisnis Katering Bayi dan Anak Maestro di Kota Semarang
}

\author{
Tri Artika Sari \\ Magister Manajemen, \\ Universitas Katolik Soegijapranata Semarang \\ email: tri.sari499@gmail.com
}

\begin{abstract}
This study aims to find out business planning on Catering Babies and Children Maestro in Semarang City in terms of marketing, operational, human and financial resources. The location of this research is in Semarang. While the object of research that will be lifted in this research is about analysis of business planning of Catering Maestro: Baby and Child Catering in Semarang City. This business plan covers aspects of marketing, human resources, operations, and finances of a business. The type of data in this study are primary and secondary data. In this study, the data collection tool uses: Library Studies and Interviews. Problem solving to be done by the researcher use two approach that is descriptive analysis qualitative. Based on the results of the analysis and discussion can be drawn conclusion as follows: "MAESTRO" business planning in terms of marketing, operational, human and financial resources is feasible because has a clear STP, 7P mix appropriate marketing, projected demand and supply, as well as a clear market share, as well as projections for marketing costs, has clear business location, and a good business layout, has details about the organizational structure, job description and the number of existing labor, the investment, as well as business feasibility ie NPV positive, $P I>1, P P<5$ years, and IRR $>$ interest rate
\end{abstract}

Keywords: planning, marketing, operational, SDM, finance.

\begin{abstract}
Abstrak
Penelitian ini bertujuan untuk mengetahui perencanaan bisnis pada Katering Bayi Dan Anak Maestro Di Kota Semarang ditinjau dari aspek pemasaran, operasional, sumber daya manusia dan keuangan. Lokasi penelitian ini adalah di Semarang. Perencanaan bisnis ini meliputi aspek pemasaran, SDM, operasi, dan keuangan dari suatu bisnis. Jenis data pada penelitian ini adalah data primer dan sekunder. Pada penelitian ini, alat pengumpulan datanya menggunakan: Studi Kepustakaan dan Wawancara. Pemecahan masalah yang akan dilakukan oleh peneliti menggunakan dua pendekatan yaitu analisis secara deskriptif kualitatif. Berdasarkan pada hasil analisis dan pembahasan dapat ditarik kesimpulan sebagai berikut: Perencanaan bisnis “MAESTRO” ditinjau dari aspek pemasaran, operasional, sumber daya manusia dan keuangan adalah layak karena ditinjau dari aspek pemasaran memiliki STP yang jelas, 7P bauran pemasaran yang tepat, proyeksi permintaan dan penawaran, serta market share yang jelas, serta proyeksi untuk biaya pemasaran. adanya lokasi usaha yang jelas, dan layout usaha yang baik, memiliki perincian tentang struktur organisasi, job description serta jumlah tenaga kerja yang ada, ditinjau dari aspek keuangan dikatakan layak karena memiliki perincian tentang investasi, serta kelayakan usaha yaitu NPV positif, PI $>1$, PP $<5$ tahun, dan IRR > suku bunga.
\end{abstract}

Kata kunci: perencanaan, pemasaran, operasional, SDM, keuangan. 


\section{PENDAHULUAN}

Makanan merupakan kebutuhan primer, maka dari itu pertumbuhan bisnis kuliner makin lama semakin berkembang seiring dengan perkembangan jaman. Banyak bisnis kuliner yang sudah berjalan dari warung tenda, warung makan, cafe, restoran dan katering baik itu rumahan maupun industri. Salah satu bisnis rumahan yang paling menguntungkan dengan pertumbuhan tinggi dan potensi perkembangan yang signifikan yaitu Bisnis Katering.

Pentingnya perencanaan bisnis katering ini, maka perlu dilakukan kajian mendalam mengenai seluk beluk bisnis katering terutama mengenai besarnya peluang bisnis. Selain itu, juga mengenai prospek bisnis ke depan (Shalman, 1997). Penanganan usaha jasa katering ada yang berada di bawah koordinasi perusahaan tertentu, hotel atau organisasi sejenis, sehingga menjadi bagian yang selama ini populer dengan divisi food and beverage di bawah manajemen tingkat menengah atau manajemen operasi lembaga bersangkutan. Ada juga usaha jasa katering yang berdiri sendiri (independent) bukan merupakan bagian dari satu unit usaha lembaga tertentu.
Usaha katering dalam penelitian ini difokuskan pada katering bayi dan anak.Bayi adalah individu berusia 0-24 bulan, sedangkan anak adalah individu berusia 2-12 tahun (Hurlock, 2012).Menurut Newman dan Newman(2009) bayi umumnya diperkenalkan dengan makanan padat pada usia 6 bulan, karena pada usia ini umumnya bayi sudah siap menerima makanan padat selain adanya kebutuhan gizi yang mungkin sudah tidak dipenuhi oleh ASI eksklusif. Mengingat usia ini bayi baru berkenalan dengan makanan padat maka ada karateristik dari makanan yang bisa dikonsumsi oleh bayi, seperti tekstur makanan lebih lembut dan encer, porsi konsumsi sedikit, terdapat interval waktu untuk variasi makanan, tidak boleh menambahkan gula, garam, atau zat adiktif karena bayi rentan terhadap alergi. Seiring usia, tekstur makanan, variasi makanan, dan kuantitas makanan semakin bervariasi.

Perencanaan bisnis katering bayi dan anak disusun dengan pertimbangan sebagai berikut:

1. Peluang pasar yang dilihat dari jumlah bayi dan anak di Kota Semarang.

Angka kelahiran bayi di Kota Semarang pada tahun 2011 sebanyak 40.336 kelahiran dan menurun menjadi 25.295 kelahiran (62,71\%) pada tahun 2012. Namun, angka kelahiran ini meningkat menjadi 35.818 kelahiran (141,60\%) pada 
tahun 2013. Hal ini menunjukkan angka kelahiran bayi cenderung berfluktuasi. Mengingat sasaran dari Bisnis Katering Maestro adalah orangtua yang memiliki bayi dan anak, maka jumlah bayi dan anak yang relatif besar mengindikasikan besarnya peluang pasar. Penurunan yang terjadi pada tahun 2012 dikarenakan pada saat itu sedang dilaksanankan program KB.

2. Tingginya kasus gizi buruk pada bayi dan anak.

Kasus-kasus gizi buruk pada balita mengindikasikan asupan gizi pada balita kurang memadai, sehingga perlu dicari solusi untuk mengatasinya. Mengingat kasus gizi buruk banyak dialami oleh masyarakat ekonomi ke bawah, maka perlu dibuat produk yang murah namun tetap berkualitas. Bisnis Katering Maestro merencanakan subsidi silang dalam bisnisnya, dengan demikian tetap dapat melayani katering bayi dan makanan dengan harga yang terjangkau namun tetap memiliki mutu yang berkualitas.

\section{Tingginya angka anak tidak sarapan pagi}

Katering Maestro memiliki banyak pegawai dan setiap pegawai memiliki tugas dan kewajiban masing-masing. Pengantar memiliki hubungan langsung dengan proses produksi, sehingga para pegawai sudah memiliki target waktu untuk menyelesaikan semuanya. Sehingga pesanan yang dikirimkan bisa tepat waktu dan tidak menggangu tugas dari setiap pegawainya.

4. Maraknya kasus-kasus keracunan produk makanan dan minuman

Saat ini marak diberitakan kasus keracunan produk makanan dan minuman pada anak-anak, seperti sosis, nugget, permen, bubur, mie, dan lain-lain. Selain itu, saat ini juga banyak beredar produk makanan dan minuman untuk anak-anak yang berbahaya bagi kesehatannya karena mengandung zat adiktif sintetis atau penggunaan bahan makanan layanan yang tidak layak konsumsi (tidak memenuhi standar kesehatan).

\section{Sedikit kompetitor}

Usaha katering di Kota Semarang relatif banyak, yaitu berdasarkan hasil penelusuran di telpon.info diketahui di Kota Semarang terdapat 173 usaha katering. Usaha katering ini umumnya bergerak di katering pesta, katering harian karyawan, nasi kotak, snack dan kue kering. Sementara katering khusus bayi dan anak relatif masih terbatas.

Berdasarkan penjabaran di atas, maka penulis tertarik untuk membuat sebuah perencanaan bisnis yang diberi judul "PERENCANAAN BISNIS KATERING BAYI DAN ANAK MAESTRO DI KOTA SEMARANG”. 
Berdasarkan penjabaran tersebut, maka perumusan masalahnya adalah sebagai berikut: "Bagaimanakah perencanaan bisnis KATERING MAESTRO (Katering Bayi dan Anak berbahan dasar organik ) di Kota Semarang?”

Tujuan penelitian ini adalah menyusun perencanaan bisnis KATERING MAESTRO (Katering Bayi dan Anak) di Kota Semarang.

\section{METODE PENELITIAN}

\section{Objek dan Subjek Penelitian}

Objek penelitian ini adalah perencanaan bisnis Katering Maestro: Katering Bayi dan Anak di Kota Semarang. Perencanaan bisnis ini meliputi aspek pemasaran, SDM, operasi, dan keuangan dari suatu bisnis. Subjek penelitian ini adalah individu-individu yang dapat memberikan informasi yang relevan dan akurat mengenai bisnis katering, sehingga perencanaan bisnis yang disusun menjadi relevan.

\section{Jenis Data}

Penelitian ini menggunakan data subjek (self-report data). Data subjek yang akan dilaporkan berisi tentang rasa makanan pada Katering Maestro, warna yang ada dalam makanan, bahan yang seperti apa yang digunakan, variasi bentuk yang digunakan saat menghias makanan sehingga membuat anak tertarik untuk memakannya, perbedaan rasa untuk bayi dan anak-anak yang seperti apa yang diberikan Katering Mestro, dan proses pembuatan makanan catering.

\section{Sumber Data}

Sumber data dalam penelitian ini merupakan data primer dan sekunder. Data primer berasal dari hasil wawancara terhadap informan penelitian (Indriantoro \& Supomo, 2010).

\section{Metode Pengumpulan Data}

Metode pengumpulan data dalam penyusunan perencanaan bisnis ini menggunakan studi kepustakaan dan wawancara.

\section{Metode Analisis Data}

Metode analisis data dalam penelitian ini adalah analisis deskriptif kualitatif. Selain itu, juga digunakan statistik deskriptif yang tujuannya sebagai teknik analisis pendukung untuk memberikan deksripsi yang lebih komprehensif dari hasil analisis kualitatif.

\section{Perencanaan Bisnis}

Perencanaan bisnis merupakan suatu dokumen tertulis yang mendeskripsikan kondisi saat ini dan kemungkinan di masa depan dari suatu organisasi (Honig dan Karlsson, 2004). Menurut Melloy (1998), 
perencanaan bisnis mencakup diskusi mengenai konsep bisnis, perencanaan operasional, perencanaan marketing, persoalan keuangan, struktur organisasi dan hukum. Oleh karena itu, bisnis tersebut harus dituangkan dalam suatu perencanaan tertulis yang mencakup area fungsional, yaitu pemasaran, sumber daya manusia, operasional, dan keuangan.

\section{Pemasaran}

Pemasaran memiliki arti lebih dari sekedar menjual dan mempromosikan suatu produk. Menurut Kotler (2012), pemasaran adalah proses sosial dengan proses itu, individu dan kelompok mendapatkan apa yang mereka butuhkan dan inginkan dengan menciptakan, menawarkan, dan secara bebas mempertukarkan produk jasa yang bernilai kepada pihak lain. Dengan kata lain, aspek pemasaran menjadi salah satu aspek penting yang dikaji dalam perencanaan bisnis, karena berfungsi untuk mendefinisikan, mengantisipasi, membuat dan memenuhi kebutuhan serta keinginan dari konsumen terhadap produk dan layanan (David, 2003). Pada perencanaan bisnis ini aspek pemasaran yang dikaji meliputi segmentasi, targeting, positioning, dan bauran pemasaran jasa.

\section{Sumber Daya Manusia}

Aspek Sumber Daya Manusia (SDM) berkaitan dengan tenaga kerja yang dapat menunjang dan mempengaruhi kegiatan operasional perusahaan (Noe, et al., 2007).

\section{Operasional}

Manajemen operasional adalah suatu fungsi atau kegiatan manajemen yang meliputi perencanaan, organisasi, staffing, koordinasi, pengarahan dan pengawasan terhadap operasi perusahaan (Umar, 2003). Fungsi operasi suatu bisnis mencakup semua aktifitas yang mengubah input menjadi barang atau jasa. Dengan kata lain, fungsi operasi merupakan fungsi yang menggerakkan sumber daya dan kapabilitas yang ada untuk melakukan proses produksi.

\section{Keuangan}

Aspek keuangan dari perencanaan bisnis mencakup kebutuhan modal, sumber dana, perkiraan pendapatan dan biaya dari perencanaan bisnis selama kurun waktu tertentu. Dengan demikian, fungsi keuangan mencakup merancang dan menetapkan keputusan-keputusan dalam hal investasi, pembiayaan dan pembagian dividen (David, 2003). Tujuan dari fungsi adalah penunjang bisnis dengan mempertahankan kondisikondisi yang berkaitan dengan faktor-faktor keuangan agar aktifitas-aktifitas perusahaan dapat berjalan dengan baik. Tolok ukur 
keberhasilan dari fungsi ini adalah (1) kesesuaian antara budget yang direncanakan di awal tahun dengan implementasi pendanaan; dan (2) bersifat administratif mengenai pencatatan, penyimpanan dan pelaporan aktifitas keuangan yang terjadi selama perusahaan beroperasi.

Bisnis katering termasuk ke dalam usaha jasaboga. Menurut Keputusan Menteri Kesehatan Republik Indonesia Nomor 715/Menkes/SK/V/2003, jasaboga adalah perusahaan atau perorangan yang melakukan kegiatan pengelolaan makanan yang disajikan di luar tempat usaha atas dasar pesanan. Pengelolaan makanan memiliki pengertian sebagai kegiatan yang meliputi penerimaan bahan mentah atau makanan terolah, pembuatan, pengubahan bentuk, pengemasan dan pewadahan.

Persyaratan pangan olahan organik menurut Peraturan Kepala Badan Pengawas Obat dan Makanan Republik Indonesia Nomor HK.00.06.52.0100 tentang Pengawasan Pangan Olahan Organik adalah pangan olahan organik wajib memenuhi persyaratan keamanan, mutu dan gizi pangan serta memenuhi ketentuan tentang pelabelan dan periklanan yang berlaku. Pangan olahan organik harus mengandung bahan pangan organik sekurang-kurangnya 95\% dari total berat atau volume, tidak termasuk air dan garam. Bahan pangan non organik yang digunakan dalam pangan olahan organik sebanyak-banyaknya 5\% dari total berat atau volume tidak termasuk air dan garam.

\section{HASIL PENELITIAN}

\section{Manajemen Pemasaran}

\section{Segmentasi}

1. Segmentasi Geografis:

Segmentasi geografis mengharuskan pembagian pasar menjadi unit-unit geografis yang berbeda seperti negara, negara bagian, wilayah, propinsi, kota, atau lingkungan rumah tangga.

Katering Maestro melayani segmen geografis adalah masyarakat kota Semarang sekitarnya pada umumnya.

2. Segmentasi demografi:

Segmentasi yang membagi pasar menjadi kelompok berdasarkan variabel-variabel demografik, yaitu:

a. Umur, yaitu membagi pasar menjadi kelompok umur yang berbeda.

Katering Maestro melayani umur dewasa khususnya sebagai segmen pasarnya, yaitu bayi berusi 6-12 bulan dan anakanak 2-12 tahun.

b. Kelas sosial, yaitu membagi pasar menjadi kelompok kelas sosial yang berbeda.

Katering Maestro melayani kelas sosial menengah 
c. Jenis kelamin, yaitu membagi pasar menjadi kelompok berbeda berdasarkan jenis kelamin.

Katering Maestro melayani jenis kelamin pria dan wanita, sebagian besar terutama adalah wanita.

d. Pendapatan, yaitu membagi pasar menjadi kelompok pendapatan yang berbeda.

Katering Maestro melayani masyarakat berpendapatan menengah

\section{Targeting}

Katering Maestro membidik pada kaum orang tua yang memiliki anak usia 6 bulan hingga 12 tahun tahun. Sehingga dengan target tersebut. Secara geografis, target pasarnya adalah masyarakat Kota Semarang, dan secara demografi adalah mereka dari kelas sosial menengah, yang didominan dengan jenis kelamin perempuan dan berusia antara 31-60 tahun. Katering Maestro memang melayani bayi berusia 612 bulan dan anak-anak 2-12 tahun, tetapi target pasar kita dalah para ibu-ibu yang berusia 31-60 tahun. Ibu-ibu berusia 31-60 tahun kebanyak adalah seorang karyawan, sehingga tidak sempat untuk menyiapkan makan untuk anaknya saat diditipkan atau saat anaknya berangkat sekolah. Jadi untuk menghindari kerepotan, para ibu memesan makanan pada Katering ini.

\section{Positioning}

Positioning penting untuk menempatkan dimana bisnis akan dimulai. Dalam usaha ini Katering Maestro menjadi pengikut pasar (follower), tetapi menjadi follower tidak berarti akan kehabisan segmen pasar. Unsur utama bisnis ini adalah jasa, jadi pelayanan yang terbaik (misalnya 3S, Senyum, Salam, Sapa, ramah dan sopan kepada konsumen, menanggapi komplain dengan cepat) adalah yang akan diberikan kepada konsumen. Maestro Catering menjadi market follower dari My Meal dan akan menjadi market challenger, alasan dipilihnya My Meal sebagai pesaing utama karena memiliki STP yang sama. Usaha ini adalah usaha yang dapat menyalurkan hobi memasak sekaligus berbisnis. Oleh sebab itu usaha catering selalu mempunyai banyak pesaing yang bekerja dalam bidang yang sama. Terkait dengan hal tersebut maka Katering Maestro menempatkan usaha catering ini dalam posisi market challenger.

\section{Program Bauran Pemasaran Produk}

Produk yang ditawarkan oleh katering balita yaitu mencangkup makanan bayi usia 6 bulan-24 bulan dan anak berusia 2 tahun12 tahun. Produk yang ditawarkan berupa makanan yan terdiri dari makanan pokok, lauk pauk, sayur, pudding atau buah. Makanan yang diberikan kepada bayi dan 
anak harus memiliki asupan gizi yang baik, bersih, halal, dan aman.

\section{Price}

Harga yang ditawarkan oleh Katering Maestro dipatok dengan harga yang relative murah sehingga tidak memberatkan para ibu rumah tangga. Harga akan menyesuaikan dengan paket yang diambil atau dipesan. Harga dari katering ini menentukan kualitas dari makanan yang diberikan yaitu makanan yang memiliki gizi tingi dan terjamin kebersihannya.

\section{Promotion}

Promosi yang dilakukan oleh Katering Maestro yaitu dengan memuat pada media massa seperti rilis koran, penyebaran brosur, pemberitaan melalui internet (social media) dan pemasangan spanduk. Hal ini dilakukan untuk mempermudah komunikasi konsumen kepada katering dan pemberitaan secara luas kepada masyarakat dan mempermudah serta mempercepat pemberitaan kepada konsumen.

\section{Place}

Saluran distribusi dari Maestro Katering ke konsumen langsung yang dilakukan oleh Katering Maestro ini yaitu pemasaran di sekitar wilayah dimana catering didirikan. Hal ini dimaksudkan agar makanan balita yang dipesan oleh konsumen tidak busuk dan tetap dalam keadaan fresh dan tetap bergizi. Hal ini dilakukan dengan cara Katering Maestro memiliki 2 kurir yang bertugas untuk mengantarkan setiap pesanan di wilayah Semarang. Selain itu untuk pesanan konsumen dalam satu lokasi misalnya di sekolah dapat menjangkau beberapa konsumen sekaligus dengan mengirim di satu tempat (dropship). Katering berada di Jalan Sanggung Raya no. 143 karena dinilai memiliki posisi yang strategis untuk pemasaran.

\section{Permintaan dan Kapasitas Produksi Proyeksi permintaan diambil dari dua pesaing dari sumber data primer 2017, sebagai berikut:}

1. Bebiluck : 15.000 box (2014), 16.500 box (2015), 18.900 box (2016). Kenaikan 10\% (2014-2015), 15\% (2015-2016), rata-rata pertumbuhan $12 \%$.

2. My Meal : 22.500 box (2014), 25.500 box (2015), 30.000 box (2016). Kenaikan 13\% (2014-2015), 18\% (2015-2016), rata-rata pertumbuhan $15 \%$.

Bebiluck dan My Meal mengalami rata-rata pertumbuhan $14 \%$.

\section{Proyeksi permintaan Katering Maestro (data primer 2017) :}

24.000 box (2017), 27.360 box (2018), 31.190 box (2019), 35.557 box (2020), 40.535 box (2021).

Asumsi kenaikan 14\% berdasarkan survey pesaing (data history). Proyeksi 5 
tahun didasarkan dari survey dua pesaing terdekat. Karena Katering Maestro mengikuti atu follower Katering My Meal, maka diasumsikan menargetkan 80\% dari pangsa pasar My Meal. 80 box/ hari x 25 hari kerja x 12 bulan (untuk tahun pertama) $=24.000 \mathrm{box}$

Tabel 1. Kapasitas Produksi dari Katering Maestro (dalam box)

\begin{tabular}{|c|c|c|c|c|c|}
\hline Ket & $\begin{array}{c}2017 \\
\text { (dalam } \\
\text { box) }\end{array}$ & $\begin{array}{c}\mathbf{2 0 1 8} \\
\text { (dalam } \\
\text { box) }\end{array}$ & $\begin{array}{c}\mathbf{2 0 1 9} \\
\text { (dalam } \\
\text { box) }\end{array}$ & $\begin{array}{c}\mathbf{2 0 2 0} \\
\text { (dalam } \\
\text { box) }\end{array}$ & $\begin{array}{c}2021 \\
\text { (dalam } \\
\text { box) }\end{array}$ \\
\hline \hline Maestro & $59,21 \%$ & $67,50 \%$ & $76,95 \%$ & $87,72 \%$ & $100 \%$ \\
\hline
\end{tabular}

Sumber: Data Primer (2017)

Asumsi : Pada tahun kelima (2021) beroperasi dengan kapasitas penuh yaitu $100 \%$

\section{Manajemen SDM Kualifikasi Perekrutan Karyawan}

Katering

Maestro akan

mempekerjakan pria maupun wanita berdasarkan kemampuan, pengalaman dan bakat mereka. Karakteristik/syarat-syarat lain perekrutan pegawai meliputi:

1. Dapat bekerja sama dengan tim dengan baik

2. Pengalaman kerja, terutama dalam kualifikasi Restaurant, Perhotelan maupun Katering.

3. Dapat berkomunikasi dengan baik dan benar.

4. Kesehatan yang baik.
5. Memiliki kompetensi baik seperti nilai ijasah dan pendidikan

\section{Pelatihan dan Pengembangan}

Tabel 2. Program Pengembangan SDM

\begin{tabular}{|c|c|}
\hline Jabatan & $\begin{array}{c}\text { Program } \\
\text { pengembangan } \\
\text { SDM }\end{array}$ \\
\hline Staf Pemasaran & Pelatihan \\
\hline $\begin{array}{c}\text { Staff Produksi } \\
\text { (Koki dan ahli gizi) }\end{array}$ & Pelatihan \\
\hline $\begin{array}{c}\text { Staff } \\
\text { Adminisrasi/kasir/ } \\
\text { Cutomer Service }\end{array}$ & Pelatihan \\
\hline Staff Gudang & Pelatihan \\
\hline Kurir & Pelatihan \\
\hline
\end{tabular}

Sumber: Data Primer (2017)

\section{Penilaian Kinerja Karyawan}

1. Proses peninjauan kerja memberikan umpan balik rutin kepada semua karyawan atas prestasi mereka

2. Perusahaan memilki tiga jenis penilaian prestasi yang resmi sebagai berikut:

a. Pembicaraan yang berkesinambungan antara karyawan dengan Manajemen;

b. Penilaian berkala berdasarkan kriteria tertentu, atau pada akhir proyek atau penugasan atau bilamana terjadi perubahan penting dalam tingkat prestasi karyawan;

c. Penilaian tertulis setengahtahunan/tahunan resmi (Penilaian Prestasi Kerja) yang membandingkan 
pelaksanaan dan aktivitas dan prestasi kerja sejak penilaian terakhir.

3. Karyawan yang diketahui tidak memberikan kontribusi pada tingkat yang disyaratkan, akan diberi bimbingan yang jelas pada bidang-bidang tertentu yang memerlukan peningkatan dan tanggaltanggal targetnya akan ditetapkan untuk membantu pencapaiannya.

4. Penilaian Prestasi Kerja akan manjadi dasar yang dipakai untuk penyesuaian Gaji.

\section{Strategi SDM Menghadapi Tantangan ke Depan}

Mengadakan Pelatihan dan Pengembangan Karir

1. Karyawan akan diberikan pelatihan yang diperlukan untuk melaksanakan tugas mereka pada tingkat yang dibutuhkan. Ini akan melibatkan salah satu atau kombinasi dari cara-cara pelatihan berikut:

a. Pelatihan di tempat kerja

b. Kursus-kursus latihan interen mengenai topik khusus

c. Kursus-kursus latihan oleh pihak luar

2. Karyawan yang ingin mengikuti latihan harus meminta persetujuan Manajer Operasional dan Kepala Departemen

\section{Manajemen Operasional}

\section{Lokasi}

Katering Maestro berada di Jalan Sanggung Raya no. 143, kota SemarangJawa Tengah.

\section{Tenaga Kerja}

Pada katering Mestro terdapat 4 orang staff produksi, 1 orang staff administrasi, 1 orang staff gudang, 1 orang staff pemasaran dan 1 kurir.

\section{Tahap Pelaksanaan Produksi}

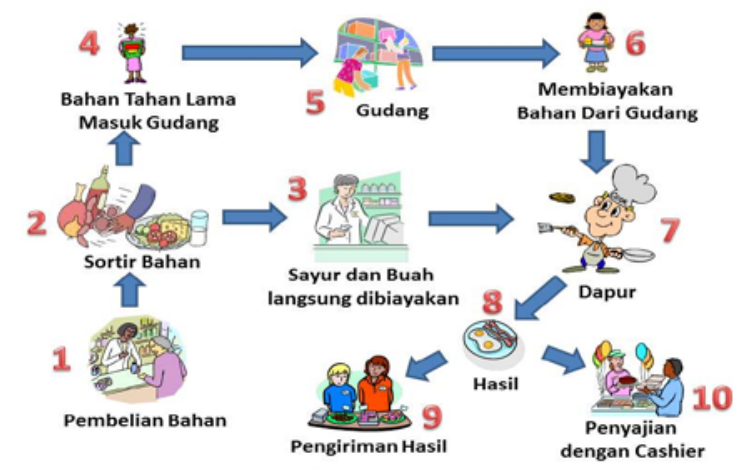

Gambar 1. Tahap Pelaksanaan Produksi pada Maestro Katering

Manajemen Keuangan

Tabel 3. Rekapitulasi Analisis Kelayakan

\begin{tabular}{|c|c|c|c|c|c|}
\hline Keterangan & $\begin{array}{c}\text { NPV (Net } \\
\text { Present } \\
\text { Value) }\end{array}$ & $\begin{array}{c}\text { PI } \\
\text { (Profita } \\
\text { billity } \\
\text { Index) }\end{array}$ & $\begin{array}{c}\text { PP } \\
\text { (Payback } \\
\text { Period) }\end{array}$ & $\begin{array}{c}\text { IRR } \\
\text { (Internal } \\
\text { Rate Of } \\
\text { Return) }\end{array}$ & $\begin{array}{c}\text { BEP } \\
\text { (Break } \\
\text { Event } \\
\text { Point) }\end{array}$ \\
\hline \hline $\begin{array}{c}\text { Keuangan } \\
\text { Normal }\end{array}$ & 459.528 .862 & 2,095 & $\begin{array}{c}2,60 \text { tahun } \\
(2 \text { th, 15 hari) }\end{array}$ & $35,733 \%$ & 20.717 \\
\hline $\begin{array}{c}\text { Keuangan } \\
\text { Optimis }\end{array}$ & 648.096 .233 & 2,585 & 2,21 tahun & $46,509 \%$ & 20.108 \\
\hline $\begin{array}{c}\text { Keuangan } \\
\text { Pesimis }\end{array}$ & 270.961 .491 & 1,630 & 3,15 tahun & $24,574 \%$ & 21.326 \\
\hline
\end{tabular}


Setelah melakukan proyeksi lima tahun ke depan yaitu membuat proyeksi laba rugi, neraca, dan arus kas, maka dalam ketiga kondisi yaitu keuangan normal, pesimis dan optimis dikatakan layak karena: NPV positif ( $>0)$, PI $>1$, PP $<5$ tahun dan IRR > suku bunga.

\section{DISKUSI}

Salah satu usaha yang mengandalkan fasilitas dan kualitas pelayanan serta promosi adalah usaha katering. Usaha ini bergerak untuk memenuhi permintaan akan pelayanan produk makanan, minuman bayi usia 6-12 bulan dan anak berusia 2-12 tahun. Usaha katering ini sedang diminati dan merebak sangat baik kota Semarang dan beberapa kota besar di Indonesia, hal ini karena meningkatnya kebutuhan akan penyedia makanan yang cepat, sehat dan sesuai kantong masyarakat. Terutama bagi keluarga yang suami dan istrinya sama-sama bekerja, dan tidak mempunyai waktu untuk memasak dan menyediakan masakan bagi anak mereka.

Untuk memenuhi keinginan konsumen, maka pelayanan ekstra berupa pelayanan luar kota pun dapat di penuhi meski di kenakan biaya tambahan sebab untuk memenuhi permintaan tersebut di bebani dengan transportasi dan tenaga tambahan. Meskipun demikian, hal ini tidak menjadi penghalang Katering Maestro untuk menyalurkan jasanya ke manapun dengan tidak mengurangi kualitas dan cita rasa nya sebab di dalamnya terdapat pegawai pegawai yang berpangalaman dan mumpuni.

Oleh karena itu, perusahaan Katering Maestro merupakan salah satu penyalur jasa katering bayi yang memberikan pelayanan terbaik. Produk atau jasa yang direncanakan untuk ditawarkan adalah (a) makanan, minuman, dan kudapan untuk bayi usia 6-12 bulan; (b) makanan, minuman dan kudapan untuk anak usia 2-12 tahun; (c) makanan, minuman, dan kudapan untuk pesta bayi dan anak; (d) jasa konsultasi gizi. Selain itu, katering ini juga menerima pemesan produk diluar menu yang tersedia. Keunggulan dari produk atau jasa katering ini adalah sertifikat halal dari MUI, sertifikat laik hygienis dari departemen kesehatan, menggunakan bahan organik khususnya untuk beras atau tepung untuk bahan baku bubur bayi 6-12 bulan (menyesuaikan permintaan dan pesanan dari konsumen), tidak menggunakan zat adiktif sintetis (perasa, pemanis, pewarna, pengawet), kemasan premium thermo box yang tahan panas, kemasan disposible ramah lingkungan dan food grade, disertakan nutrition fact, dan gratis konsultasi ahli gizi.

Ditinjau dari analisis perencanaan bisnis untuk usaha KATERING MAESTRO ditinjau dari aspek pemasaran, teknis dan operasional, aspek SDM, serta aspek keuangan adalah layak. Hal ini disebabkan 
karena dari aspek pemasaran memiliki STP yang jelas, 7P bauran pemasaran yang tepat, proyeksi permintaan dan penawaran, serta market share yang jelas, serta proyeksi untuk biaya pemasaran. Kemudian ditinjau dari aspek teknis dan operasional juga dikatakan layak karena adanya lokasi usaha yang jelas, dan layout usaha yang baik. Dilihat dari aspek SDM dikatakan layak karena memiliki perincian tentang struktur organisasi, job description serta jumlah tenaga kerja yang ada. Ditinjau dari aspek keuangan dikatakan layak karena memiliki perincian tentang investasi, serta kelayakan usaha yaitu NPV positif, PI $>1$, PP $<5$ tahun, dan IRR $>$ suku bunga.

\section{SIMPULAN}

Berdasarkan pada hasil analisis dan pembahasan pada bab sebelumnya, maka kesimpulan pada penelitian ini adalah sebagai berikut:

1. Analisis perencanaan bisnis untuk usaha KATERING MAESTRO ditinjau dari aspek pemasaran, teknis dan operasional, aspek SDM, serta aspek keuangan adalah layak.

2. Hal ini disebabkan karena dari aspek pemasaran memiliki STP yang jelas, 7P bauran pemasaran yang tepat, proyeksi permintaan dan penawaran, serta market share yang jelas, serta proyeksi untuk biaya pemasaran.
3. Kemudian ditinjau dari aspek teknis dan operasional juga dikatakan layak karena adanya lokasi usaha yang jelas, dan layout usaha yang baik.

4. Dilihat dari aspek SDM dikatakan layak karena memiliki perincian tentang struktur organisasi, job description serta jumlah tenaga kerja yang ada.

5. Ditinjau dari aspek keuangan dikatakan layak karena memiliki perincian tentang investasi, serta kelayakan usaha yaitu NPV positif, PI $>1$, PP $<5$ tahun, dan IRR > suku bunga.

Oleh sebab itu pada penelitian ini dapat disarankan untuk menjalankan bisnis atau usaha KATERING MAESTRO karena ditinjau dari analisis kelayakannya dapat dinyatakan layak. Untuk penelitian selanjutnya sebainya dapat membandingkan dua katering atau mengubah usaha yang dijalankan misalnya, katering untuk anak sekolah, atau katering untuk program diet.

\section{DAFTAR PUSTAKA}

David, F.R. (2003). Strategic Management: Concepts and Cases. New Jersey: Prentice Hall.

Honig, B and Karlsson, T. (2004). Institusional Forces and the Written Business Plan. Journal of Management, Vol. 30 (1): 29-48. 
Hurlock, E.B. (2012). Psikologi Perkembangan: Suatu Pendekatan Sepanjang Rentang Kehidupan. Alih Bahasa: Istiwidayanti S. Jakarta: PT Erlangga.

Indriantoro, N dan Supomo, B. (2011). Metodologi Penelitian Bisnis untuk Akuntansi dan Manajemen. Yogyakarta: BPFE.

Kotler, P. (2012). Manajemen Pemasaran. Jilid I. Jakarta: PT Gramedia Pustaka Utama.

Newman, B.M and Newman, P.R. (2006). Development through life: A psycholosocial approach. 9th Ed. USA: Thomson Wadsworth.

Noe, R.A., Hollenback, J.R., Gerhart, B., \& Wright, P.M. (2007). Human Resource Management: Gaining a Competitive Advantage. Boston: McGrawHill/Irwin.

Umar, H. (2003). Studi Kelayakan Bisnis: Teknik Menganalisis Kelayakan Rencana Bisnis Secara Komprehensif. Edisi 2. Jakarta: PT Gramedia Pustaka Utama. 